ADVANCES IN MAGNETOSPHERIC PHYSICS WITH GEOS-1 AND ISEE 


\title{
ADVANCES IN \\ MAGNETOSPERIC PHYSICS WITH GEOS-1 AND ISEE
}

\author{
EDITED BY \\ K. KNOTT \\ and \\ A. DURNEY and K. OGILVIE
}

Reprinted from:

Space Science Reviews, Vol. 22, Nos. 4/5/6, and Vol. 23, No. 1, 1978/79

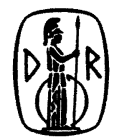

D. REIDEL PUBLISHING COMPANY

DORDRECHT : HOLLAND / BOSTON : U.S.A.

LONDON : ENGLAND 
ISBN:-13: 978-94-009-9529-1

e-ISBN-13: 978-94-009-9527-7

DOI: $10.1007 / 978-94-009-9527-7$

All Rights Reserved

Copyright (C) 1979 by D. Reidel Publishing Company, Dordrecht, Holland

Softcover reprint of the hardcover 1st edition 1979

No part of the material protected by this copyright notice may be reproduced or utilized in any form or by any means, electronic or mechanical,

including photocopying, recording or by any informational storage and retrieval system, without written permission from the copyright owner 


\section{TABLE OF CONTENTS}

PART I: GEOS-1 WAVE AND FIELD EXPERIMENTS

FOR GEOS S-300 EXPERIMENTERS (D. JONES) / Introduction to the S-300

Wave Experiment Onboard GEOS

A. PEDERSEN, R. GRARD, K. KNOTT, D. JONES, A. GONFALONE, and

U. FAHLESON / Measurements of Quasi-Static Electric Fields between 3 and

7 Earth Radii on GEOS-1

S. PERRAUT, R. GENDRIN, P. ROBERT, A. ROUX, C. DE VILLEDARY, and

D. JONES / ULF Waves Observed with Magnetic and Electric Sensors on GEOS-1

NICOLE CORNILLEAU-WEHRLIN, ROGER GENDRIN, FRANÇOIS LEFEUVRE, MICHEL PARROT, REJEAN GRARD, DYFRIG JONES, AXEL BAHNSEN, EIGEL UNGSTRUP, and WARWICK GIBBONS / VLF Electromagnetic Waves Observed Onboard GEOS-1

P. J. CHRISTIANSEN, M. P. GOUGH, G. MARTELLI, J. J. BLOCH,

N. CORNILLEAU-WEHRLIN, J. ETCHETO, R. GENDRIN, C. BEGHIN,

P. DECREAU, and D. JONES / GEOS-1 Observations of Electrostatic Waves, and their Relationship with Plasma Parameters

K. RÖNMARK, H. BORG, P. J. CHRISTIANSEN, M. P. GOUGH, and

D. JONES / Banded Electron Cyclotron Harmonic Instability - A First

Comparison of Theory and Experiment

NICOLE CORNILLEAU-WEHRLIN, ROGER GENDRIN, and MICHEL TIXIER /

VLF Waves: Conjugated Ground-Satellite Relationships

ROGER GENDRIN, SYLVAINE PERRAUT, HERVÉ FARGETTON, FRANÇOIS

GLANGEAUD, and JEAN-LOUIS LACOUME / ULF Waves: Conjugated

Gound-Satellite Relationships

NICOLE CORNILLEAU-WEHRLIN, ROGER GENDRIN, and RICHARD PEREZ /

Reception of the NKL (Jim Creek) Transmitter Onboard GEOS-1

E. UNGSTRUP, T. NEUBERT, and A. BAHNSEN / Observation on GEOS-1 of 10.2 to $13.6 \mathrm{kHz}$ Ground Based Transmitter Signals

M. A. MADDEN, M. J. RYCROFT, and N. L. SMITH / Ground-Based ELF/VLF

Observations at High Latitudes during Passes of GEOS-1 and ISEE-1 and -2

J. C. KOSIK / The Uses of Past and Present Magnetospheric Field Models for Mapping Fluxes and Calculating Conjugate Points 


\section{PART II: GEOS-1 PLASMA AND PARTICLE EXPERIMENTS}

A. KORTH, G. KREMSER, and B. WILKEN / Observations of SubstormAssociated Particle-Flux Variationas at $6 \leqslant L \leqslant 8$ with GEOS- 1

H. BORG, L.-A. HOLMGREN, B. HULTQVIST, F. CAMBOU, H. REME, A. BAHNSEN, and G. KREMSER / Some Early Results of the keV Plasma Experiment on GEOS-1

J. GEISS, H. BALSIGER, P. EBERHARDT, H. P. WALKER, L. WEBER,

D. T. YOUNG, and H. ROSENBAUER / Dynamics of Magnetospheric Ion Composition as Observed by the GEOS Mass Spectrometer

J. F. E. JOHNSON, J. J. SOJKA, and G. L. WRENN / Thermal/Suprathermal Plasmas Observed by the S-302 Experiment on GEOS-1

P. M. E. DECREAU, C. BEGHIN, and M. PARROT / Electron Density and

Temperature, as Measured by the Mutual Impedance Experiment on Board GEOS-1

J. ETCHETO and J. J. BLOCH / Plasma Density Measurements from the GEOS-1 Relaxation Sounder

B. HIGEL / Small Scale Structure of Magnetospheric Electron Density Through On-Line Tracking of Plasma Resonances

P. M. E. DecreaU, J. ETChETO, K. KNOTT, A. PEDERSEN, G. L. WRENN, and D. T. YOUNG / Multi-Experiment Determination of Plasma Density and Temperature

B. WILKEN, T. A. FRITZ, A. KORTH, and G. KREMSER / Substorm-Associated Injections of Energetic Ions Observed by GEOS-1 and ATS-6 in and near Synchronous Altitude

T. A. POTEMRA, C. O. BOSTROM, J. P. DOERING, and J. S. LEE / Observations of Low-Energy Electrons from AE-C in the South Polar Cusp durnig the Geomagnetic Storm of September 21, 1977

M. CANDIDI, H. W. KROEHL, G. KOSINSKI, and R. W. BUHMANN / DMSP-F2 Observations of Cusplike Electron Precipitation Regions during the September 19-21, 1977 Event

A. C. DURNEY and K. W. OGILVIE / Introduction to the ISEE Mission

\section{PART III: MAGNETOPAUSE AND MAGNETOSHEATH OBSERVATIONS}

C. T. RUSSELL and R. C. ELPHIC / Initial ISEE Magnetometer Results: Magnetopause Observations

G. PASCHMANN, N. SCKOPKE, G. HAERENDEL, J. PAPAMASTORAKIS,

S. J. BAME, J. R. ASBRIDGE, J. T. GOSLING, E. W. HONES, JR., and

E. R. TECH / ISEE Plasma Observations near the Subsolar Magnetopause 
L. A. FRANK, K. L. ACKERSON, R. L. DeCOSTER, and B. G. BUREK / Three-Dimensional Plasma Measurements within the Earth's Magnetosphere

G. K. PARKS, C. GURGIOLO; C. S. LIN, K. A. ANDERSON, R. P. LIN, F. MARTEL, and H. RÈE / Dual Spacecraft Observations of Energetic Particles in the Vicinity of the Magnetopause, Bow Shock, and the Interplanetary Medium

J. P. HEPPNER, N. C. MAYNARD, and T. L. AGGSON / Early Results from ISEE-1 Electric Field Measurements

F. S. MOZER, R. B. TORBERT, U. V. FAHLESON, C.-G. FÄLTHAMMAR, A. GONFALONE, and A. PEDERSEN / Electric Field Measurements in the Solar Wind, Bow Shock, Magnetosheath, Magnetopause, and Magnetosphere

D. J. WILLIAMS, T. A. FRITZ, E. KEPPLER, B. WILKEN, and G. WIBBERENZ / Three-Dimensional Energetic Ion Observations and the Tangential Magnetopause Electric Field

\section{PART IV: SOLAR WIND AND BOW SHOCK OBSERVATIONS}

C. T. RUSSELL and E. W. GREENSTADT / Initial ISEE Magnetometer Results: Shock Observation

C. C. HARVEY, J. ETCHETO, and A. MANGENEY / Early Results from the ISEE Electron Density Experiment

M. B. BAVASS ANO-CATTANEO, C. BONIFAZI, P. CERULLI-IRELLI,

L. DiOdATE, M. DOBROWOLNY, A. EGIDI, G. MORENO, and S. ORSINI /

Preliminary Results from the Solar Wind Experiment on the ISEE-2 Satellite

S. J. BAME, J. R. ASBRIDGE, J. T. GOSLING, M. HALBIG, G. PASCHMANN, N. SCKOPKE, and H. ROSENBAUER / High Temporal Resolution Observations of Electron Heating at the Bow Shock

F. M. IPAVICH, G. GLOECKLER, C. Y. FAN, L. A. FISK, D. HOVESTADT, B. KLECKER, J. J. O'GALLAGHER, and M. SCHOLER / Initial Observations of Low Energy Charged Particles Near the Earth's Bow Shock on ISEE-1

D. A. GURNETT, R. R. ANDERSON, F. L. SCARF, R. W. FREDRICKS, and E. J. SMITH / Initial Results from the ISEE-1 and -2 Plasma Wave Investigation

K. W. OGILVIE and J. D. SCUDDER / First Results from the Six-Axis Electron Spectrometer on ISEE-1 


\title{
INTRODUCTION
}

\author{
(Opening Address of 13th ESLAB Symposium)
}

With GEOS and ISEE occupying a major part of the ESA scientific programme it was clear several years ago that a 'natural' basis for the 1978 ESLAB Annual Symposium would be the early data from these two spacecraft. During the 1976 meeting of the European Geophysical Society in Amsterdam it became apparent to me that a much wider community was interested and that in particular Working Group 2 of COSPAR was considering a GEOS session during its 1978 meeting here in Innsbruck. This was of course as it ought to be because GEOS had been adopted as the reference spacecraft for the International Magnetospheric Study. After some discussions with COSPAR and with the organizers of the STP Symposium which was held here last week we felt that in the interest of customer relations and following good common sense we should give up some of our independence in 1978 and merge our Symposium with COSPAR. I would gratefully acknowledge the co-operation of COSPAR's Working Group 2 chairman and vice-chairman, the active support of the President of COSPAR and the 'gentleman's agreement' with the STP programme committee which arranged that the new ISEE and GEOS results were routed to this Symposium rather than to the STP.

I have talked about how we came to have this joint Symposium. Perhaps I should tell you too how we came close to having no Symposium. Just before dawn on 20 April last year Karl Knott and I stood on the roof of a building at NASA's Eastern Test Range watching one of the most colourful launches I have seen. At ground level it was still dark and the rocket took off illuminating the surrounding countryside in orange. Higher up dawn had arrived and the vehicle trail was beautifully illuminated in a cloudless sky. All looked perfect. A short time later, back within the control centre we learned however, that GEOS could not be placed in a geostationary orbit and indeed we were to discover that we were lucky to be in any orbit at all. Worries about radiation damage forced us to make a quick decision between the only two real alternatives which were injection into a 12-hour orbit with apogee close to the original geostationary position or injection into a 24-hour orbit with apogee in interplanetary space for much of the year. We chose the 12-hour orbit and are still in the process of being forgiven by several experimenters especially (p)ioneers - who longed to get into the solar wind with their sophisticated new analyser.

Because of this mishap GEOS could no longer be reasonably described as the reference spacecraft for the IMS and in a formal sense had to be classified as a failure. In the next two days we are to hear of some of the excellent scientific measurements made during this 'failed' mission. The spacecraft and experiments have worked very well.

I believe the idea of ESA and NASA getting together on what is now called the ISEE mission came from Dr. Meredith of Goddard Space Flight Centre during a visit to Space Science Department at ESTEC. At that time many people were thinking in terms of 
flying several spacecraft together through the magnetosphere in order to sort out space/ time ambiguities and NASA was considering a mission called IMP $\mathrm{K}-\mathrm{K}^{\prime}$. After several changes of name we eventually arrived at 'International Sun Earth Explorer' and in October last year NASA launched the first two of the three-satellite mission - the 'daughter' spacecraft having been built by ESA. Data has been a bit slow in appearing - in particular the much discussed data pool tape - and I am looking forward to seeing the first results at this Symposium. It will be particularly interesting to me to see where the two spacecraft have made major advances over what could have been achieved by one spacecraft. This demonstration is required in order to reply to those critics who dismissed the mission as just one more trip at random into the magnetosphere.

We trust that our ESA contributions to ISEE and GEOS and our participation in the IMSCIE Boulder co-ordination centre have been useful inputs to the IMS. We hope too that this Symposium will be a significant landmark in the scientific output from the IMS. We thank you all for your interest and look forward to two days of exciting contributions and lively discussion.

D. E. PAGE

Head Space Science Department of ESA 